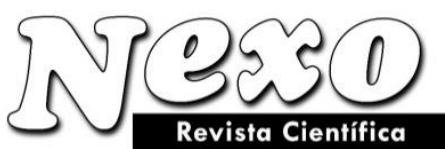

Vol. 34, No. 01, pp. 270-279/Marzo 2021

\title{
Ensuring fire safety in cluster animal industrial complex
}

\section{Aseguramiento de protección contra el fuego en complejos industriales de agrupaciones animales}

\author{
Anatoly P. Savelyev *, Sergey V. Glotov, Mikhail N. Chugunov, Svetlana A. Enaleeva \\ Ogarev Mordovia State University, Russia. \\ *tb280@mail.ru
}

(recibido/received: 19-November-2020; aceptado/accepted: 18-January-2021)

\begin{abstract}
This study deals with ensuring fire safety in buildings of a cluster animal industrial complex by optimizing legislative measures and analyzing factors that affect the quality and reliability of the results of calculating fire risk. The research involved the following methods: expert assessment; calculating individual fire risk; modeling evacuation of people in the form of an individual flow model of human traffic. The conceptual features of the complex's buildings required developing the design and technical solutions that would reduce inefficient costs on the one hand, and, on the other, would ensure meeting fire safety requirements. The individual fire risk for employees of the asset to be protected is $2.91 \times 10-7$ per year-1 $(0.291 \times 10-6$ per year). That is, it does not exceed the characteristic value established by Federal law No. 123-FZ dated 22.07.2008 'Technical regulations on fire safety'. After the introduction of the fire risk assessment system at the legislative level, the owners of objects have received the opportunity to optimize the cost of fire safety and the required level of human safety.
\end{abstract}

Keywords: Automatic fire alarm system; Individual fire risk; Fire safety system; Smoke exhaust system; System of warning and management of people evacuation in case of fire.

\section{RESUMEN}

Aquí se presenta el estudio del aseguramiento de la protección contra el fuego en edificios agrupados de un conjunto de ganadería por medio de optimizar las medidas legislativas respectivas y analizar las influencias en la calidad y fiabilidad de los resultados de evaluar riesgos de incendio. Se llevaron a cabo los estudios a través de hacer valoración profesional, calcular riesgos de incendio individuales y simular la evacuación de la gente en el modelo de flujos humanos individual y en cadena. Los aspectos funcionales conceptuales de los edificios del conjunto resultaron en la necesidad de desarrollar soluciones técnicas y estructurales que podrían ayudar a reducir gastos ineficientes y armonizarían los edificios con las exigencias de la protección contra el fuego. El riesgo de incendios indivudual para los trabajadores del objeto de protección considerado es 2.91 x10-7 por año-1 (0.291x10-6 por año), es decir, no sobrepasa el nivel normal establecido por la ley Federal 123-FZ del 22 de Julio de 2008 «Regulaciones Técnicas de las Exigencias a la Protección contra el Fuego». La adopción en el nivel legislativo del sistema de valorar riesgos de incendio creó para los dueños de objetos la oportunidad de optimizar los gastos para asegurar la protección contra el fuego, incluyendo el aseguramiento del nivel exigido de seguridad humana. 
Palabras clave: Alarma de fuego automática; Riesgo de incendio individual; Sistema de asegurar la protección contra el fuego; Sistema de eliminar humos; Sistema de advertencia y control de la evacuación de personas en caso de fuego

\section{INTRODUCTION}

In accordance with article 6 of Federal law No. 123-FZ dated July 22, 2008 'Technical regulations on fire safety requirements' (hereinafter - the Technical regulations), the fire safety of an asset to be protected is provided in the following cases:

1) the fire safety requirements established by the technical regulations adopted in accordance with the Federal law 'On technical regulation' (Federal Law No. 184-FZ dated 27 December 2002) (hereinafter the Federal law) are fully met; the fire risk does not exceed the permissible values established by the Federal law (Federal Law No. 123-FZ dated 22 July 2008);

2) fire safety requirements established by technical regulations (Federal Law No. 123-FZ dated 22 July 2008; Federal Law No. 384-FZ dated 30 December 2009) approved by the Federal law and regulatory documents on fire safety (SP 1.13130.2009; SP 2.13130.2012; SP 3.13130.2009; SP 4.13130.2013; SP 5.13130.2009; SP 7.13130.2013; SP 8.13130.2009; 1SP 10.13130.2009; SP 12.13130.2009) are fully met.

Assessing the compliance of the asset to be protected with fire safety requirements based on fire risk calculations (Resolution of the Government of the Russian Federation dated 31 March 2009 No. 272; Order of the Ministry of Emergency Situations of Russia dated 30 June 2009 No. 382; Order of the RF Ministry of emergency situations No. 404 dated 10 July 2009; Chu \& Sun, 2008) is a promising way that allows optimizing the cost of fire safety with the unconditional provision of human safety.

\section{MATERIALS AND METHODS}

The study considers an animal industrial complex in the form of a cluster building. The materials that form the fire load were: wood and polymer materials in building structures and internal enclosing elements; polymer materials in engineering system units and process equipment (electrical insulation, combustible equipment structures); dry feed (hay, straw, etc.); combustible materials of automotive and tractor equipment used in technological processes (feed distribution, manure harvesters and other auxiliary technological machines), including flammable and combustible liquids as part of thefuel, hydraulic and other systems; office equipment and supplies in administrative and household premises.

Methods of research included:

- expert assessment based on comparison between the actual state of assets to be protected and fire safety requirements of the RF technical standards base (Federal Law No. 123-FZ; Federal Law No. 384-FZ; SP 1.13130.2009; SP 2.13130.2012; SP 3.13130.2009; SP 4.13130.2013; SP 5.13130.2009; SP 7.13130.2013; SP 8.13130.2009; 1SP 10.13130.2009; SP 12.13130.2009) and the results of scientific research of Russian and foreign researchers (Borg \& Njå, 2013; Order of the RF Ministry of emergency situations No. 649 dated 14.12.2010; NFPA 204 Standard for Smoke and Heat Venting; Robertson, Tsuchiya \& Mathieu; NIST Special Publication 1018, 1019; Rutstein, 1979);

- the fire risk calculation (Resolution of the Government of the Russian Federation dated 31 March 2009 No. 272) in accordance with the methodology for determining the ire risk at production facilities (Annex to the Order of the RF Ministry of emergency situations of dated 10.07.2009 №404) (Order of the RF Ministry of emergency situations No. 404; Chu \& Sun, 2008; Gordienko, 2012), taking into account the provisions of fire safety regulations (SP 1.13130.2009; SP 2.13130.2012; SP 3.13130.2009; SP 
4.13130.2013; SP 5.13130.2009; SP 7.13130.2013; SP 8.13130.2009; 1 SP 10.13130.2009; SP 12.13130.2009). A differential (field) fire model was used to calculate the dynamics of dangerous fire factors (DFF) Models of building parts for DFF calculating were designed in Pyrosim software by ThunderheadEngineering, USA) (SITIS 4-11: 6036-MP2 Recommendations for using the FDS);

- simulation. As a model for calculating the evacuation time in the buildings under consideration, we used an individual-flow model of the movement of human flows, which allows taking into account complex behavioral factors, including the separation of human flows, as well as the individual movement of individuals or their groups. The calculation grid for evacuation processes simulation was designed in the trial version of the Pathfinder 2018.2x64 software (by ThunderheadEngineering, USA) (Pathfinder User Manual 2017; NFPA 204 Standard for Smoke and Heat Venting, 2012).

\section{RESULTS AND DISCUSSION}

The considered building, according to the approved structural decisions, meets the mandatory fire safety requirements established by the technical regulations respecting the Federal law (Federal Law No. 123FZ).

However, there are some deviations from the voluntary fire safety requirements regarding the excess of the area of a fire compartment, the structural design of the complex (light metal structures without fire protection), lack of automatic fire extinguishing system, internal fire protection water supply, and smoke ventilation.

In this regard, there was a reason to carry out a fire risk assessment and compare it with the characteristic value. In case of appropriate fire risk, it means that the fire safety of the considered complex is provided.

The aim of this work was to estimate the fire risk by approved methods and compare the values obtained with characteristic value of fire risk for the studied building stated in article 93 of the Technical regulations (Federal Law No. 123-FZ) It also shall not exceed one millionth per year.

Depending upon the class of functional fire hazard of the considered complex F 5 (class F5.1 - production milking rooms; class F5.2 - warehouses; class F5.3 - barns and calf barns), it will be subject to the corresponding provisions of the Methodology for calculating values for industrial facilities approved by Order of the RF Ministry of emergency situations dated July 10, 2009 No. 404 (Annex to the Order of the RF Ministry of emergency situations No. 382 dated 30 July 2009). Barns and calf barns have the following fire technical characteristics: the degree of fire resistance of buildings (IV) and the class of structural fire hazard (C3).

The Technical regulations (Federal Law No. 123-FZ) and fire safety documentation (SP 1.13130.2009; SP 2.13130.2012; SP 3.13130.2009; SP 4.13130.2013; SP 5.13130.2009; SP 7.13130.2013; SP 8.13130.2009; 1SP 10.13130.2009; SP 12.13130.2009) state that the asset to be protected should be equipped with fire protection systems based on the applicable requirements for each of the buildings (taking into account the appropriate allocation of the whole complex in fire compartments or other spaceplanning, structural or technical solutions, as well as the design tasks).

The fire risk assessment was carried out for buildings that go back from the fire safety requirements, namely for barns, calf barns, and milking rooms.

Fire hazard analysis was carried out for the considered complex, including the study of building's characteristics (space-planning, design and technical solutions), fire protection systems, and functioning features (SP 50.13330.2012 'SNiP 23-02-2003; SP 131.13330.2012 'SNiP 23-01-99). The content and distribution of fire load in the premises have also been carefully analyzed. Analysis of fire hazard was 
based on design data and information obtained during the site survey and from reference and other sources of information (SFPE Handbook of Fire Protection Engineering; HaukurIngason \& Hammarstrom, 2010; Overholt et al.; Rutstein, 1979; ProfilArbed - Centre de Recherches, 1999; Arvidsson \& Hult, 2006).

The buildings of barns and calf barns are designed as a single room with a V-roof. At the same time, the buildings have crossway connections. The rooms open into the outside through the gates and wall openings that appear when the shutters are open. The similar space-planning schemes usually determine the fire spread (Molchadsky, 2005; Zozulya et al., 1974; Koshmarov, 2000): the fire occurs at the place of the fire load; the fire spreads vertically upwards according to the place of the fire load. The fire spread from the fire bed is circular taking into account the peculiarities of fire distribution; the flashover usually occurs in large rooms a long time after the fire breakout (it is not less than 10-15 min). After the flashover, the small rooms made of combustible materials burn on external surfaces; the fire dynamics is typical for the separate burning areas of fire load, i.e., the built-in space can be considered as a separate area of the fire load. During the fire spread inside the large rooms, the smoke layer is initially formed near the ceiling and gradually goes down (Puzach, 2005).

The presence of open side doors, including those appeared during the fire spread, can lead to the smoke distribution around the room, namely in its lower zone. However, usually the open doors improve visibility, i.e. the escape routes become blocked later than in buildings with closed doors. Open doors stimulate more complete burnout of the fire load and less smoke emission. Moreover, a part of the combustion products leaves the room (Zernov, 1984).

In accordance with the current concept for assessing individual fire risk provided by the Methodology (Order of the RF Ministry of emergency situations No. 404 dated 10 July 2009), evacuation in case of fire will be considered placing people in the point of the room (building) which is the farthest from the exit.

When modeling fires in barns and calf barns, besides the critical values of fire hazards, which are expressed in the impact of temperature and concentration of combustion products and oxygen, as well as in the loss of visibility, this study granted the metal structures losing their fire resistance.

If a fire occurs in barns and calf barns, it is possible to identify one possible fire scenario, which is related to the place of its occurrence and the expected development dynamics. It is when the fire occurs in one of the ends of the barn/calf barn there the tractor with a feed feeder is.

The analysis of possible causes of fires in premises and tractors was based on literature and statistical reports (Arlene Robertson).

The following fire scenarios were considered for the protection of the studied buildings: No. 1 in building 1 at the end; No. 2 in building 2 at the end; No. 3 -in the building 3 at the end; No. 4 in building 4 at the end; No. 5 in building 5 at the end; No. 6 in building 6 at the end; No. 7 in the dairy milking block: No. 7 in the veterinary disinfection area; No. 8 in the milking room.

A differential (field) fire model was used to calculate the DFF dynamics, which was selected for the following reasons:

- buildings of barns and calf barns have significant internal volumes with a V-shaped roof and a system of internal barriers (dividing walls);

- fire spread in such premises is typical of an axisymmetric convective column with a non-central location of the fire bed;

- the fire load can be local; there is a non-circular spread of combustion on the surface of combustible materials with variable power of the fire source. 
Information on the frequency of events that trigger fire for certain types of equipment and objects is provided in Appendix 1 to the Methodology (Order of the RF Ministry of emergency situations No. 404 dated 10 July 2009) and in the Manual (Gordienko, 2012).

Models of parts of building for calculating DFF were designed in the Pyrosim software (by ThunderheadEngineering, USA), which produces a text input file for calculating in the postprocessor FireDynamicsSimulator (by the national Institute of standards and technology, USA). This software is supported and improved by a number of leading scientific and research institutions in other countries since it has open code (Hammarstrom, 2010; 3 NIST Special Publication 1018, 1019).

This study covers the methodology for determining the fire risk adopted in the UK (Rutstein, 1979), Finland (Rahikainen \& Keski-Rahkonen, 1998; Tillander \& Keski-Rahkonen, 2003), France (ProfilArbed - Centre de Recherches, 1999), Sweden (Arvidsson \& Hult, 2006), Russia, and other countries (Arlene Robertson; Olawoyin, 2018). A common approach is that the fire risk depends on the area of the premises. However, the mathematical formula of this dependence is different.

Calculations have shown the model adopted in the UK stated the values of fire risk for the considered buildings be like $4.49 \times 10-2$ per year, in Finland - $1.89 \times 10-2$ per year, in France $-9.9 \times 10-2$ per year, in Sweden $-7.2 \times 10-2$ per year. Calculations using the Russian method showed that the fire risk would be as follows: for barns and calf barns $-4.49 \times 10-2$ per year; for a barn for 104 cows with problems -2.21 $\times 10-2$ per year; for a dairy milking block (without an office part) $-2.48 \times 10-2$ per year.

In accordance with the requirements of fire safety, regulating the need to equip the considered object with fire protection systems (SP 3.13130.2009, SP 5.13130.2009, SP 7.13130.2013), it should be equipped with the following fire protection systems: automatic fire alarm unit (AFAU); fire warning and evacuation management system (FWEMS); smoke protection (SP); automatic fire fighting equipment (AFFE).

Following on from the adopted design decisions based on the principles of reasonable sufficiency and the expediency of certain systems, not all fire protection systems are provided for the studied building. Barns and calf barns are equipped with FWEMS, general ventilation in the form of constantly open shaft heads at the roof level and open (adjustable) window openings. Barns and calf barns are not equipped with SP, AFFE and internal fire-fighting main due to the lack of heating. The production parts of the building of the dairy milking block are equipped with AFAU and FWEMS. The administrative parts of the dairy milking block are equipped with AFAU and FWEMS and natural ventilation in case of fire (SP). AFFE equipment is not required according to the regulations.

Calculation of the time when fire hazards reach their critical values, at which the escape routes become blocked, revealed that in all scenarios, this hazard is the loss of visibility.

The potential fire risk in the studied buildings was:

- barns and calf barns:

$\mathrm{P}=4,49 \times 10-2 \times(1-0,999) \times(1-0,03) \times(1-0,8) \times(1-0,8)=1,74 \times 10-6$;

- a barn for 104 cows with problems:

$\mathrm{P}=2,21 \times 10-2 \times(1-0,999) \times(1-0,03) \times(1-0,8) \times(1-0,8)=0,86 \times 10-6$;

- dairy milking block:

$\mathrm{P}=2,48 \times 10-2 \times(1-0,999) \times(1-0,03) \times(1-0,8) \times(1-0,8) \times(1-0,8)=0,19 \times 10-6$. 
Individual fire risk in buildings of the asset to be protected was as follows: barns and calf barns $\mathrm{R}=$ $2.91 \times 10-7$ per year, a barn for 104 cows with problems $\mathrm{R}=1.44 \times 10-7$ per year, a dairy milking block $\mathrm{R}=$ $0.63 \times 10-7$ per year.

The potential fire risk for barns, calf barns and dairy milking block will be as follows: barns and calf barns $\mathrm{P}=1.71 \times 10-6$; dairy milking block $\mathrm{P}=0.34 \times 10-6$.

Individual fire risk in this case will be as follows: barns and calf barns $\mathrm{R}=2.86 \times 10-7$ per year, dairy milking block $\mathrm{R}=1.13 \times 10-7$ per year. The calculated value of individual fire risk is the highest of all received, i.e. $2.91 \times 10-7$ per year,. This value does not exceed the normative value established by the Federal law dated 22.07.2008 No. 123-FZ and is used to confirm the compliance of the asset to be protected with fire safety requirements (Federal Law No. 123-FZ dated 22 July 2008).

Optimization of fire safety measures includes selecting the building's structural design, as well as the technical solutions that ensure meeting fire safety requirements while reducing costs.

Having accepted Technical regulations (Federal Law No. 123-FZ ) in the field of fire safety in 2008, the transition from the concept of absolute safety to the concept of acceptable risk was legally settled. When implementing the concept of absolute safety, the fire safety of cluster animal industrial complex should have been ensured by the unconditional fulfillment of all fire safety requirements stipulated by technical regulations and regulatory documents on fire safety. In this case, the studied building or its parts had to be designed and implemented with a standard degree of fire resistance and a class of constructive fire hazard, equipped with an internal fire-fighting main, equipped with an automatic fire-fighting system, automatic fire detectors, etc.

The operation of the studied building initially assumed a specific mode of its operation, that is, in conditions of negative temperatures and aggressive chemical environment. This leads to the solutions that would avoid inefficient costs. These costs include, for example, the cost of heating, installing a fullfledged foundation, taking into account the depth of soil freezing, etc. Failure to heat during sub-zero temperatures makes it impossible to operate water-containing systems, especially the systems of internal fire-fighting main and automatic fire extinguishing systems. The lack of a full-fledged foundation requires reducing the support load on the base of the building, which means that it involves the use of light structures made of light metal and external walls with polyurethane foam filling.

The design and construction of buildings for cluster animal industrial complex successfully solved a number of tasks.

The buildings are have load-bearing parts made of light metal and enclosing structures without an internal fire-fighting main and an automatic fire-extinguishing system. As a result, the building of the cluster animal industrial complex meets the requirements of fire safety since it implements the requirements stipulated by technical regulations. The justified rejection of measures that are ineffective in terms of operation of the object has increased the efficiency of economic investments.

At the same time, fire risk calculations revealed a number of factors that affect the quality and reliability of the results, which include: 1. Imperfect mathematical apparatus of calculations; 2. Imperfect models of the spread of fire hazards and evacuation; 3 . The qualification of the operator who makes the calculations. Let's look at these factors in more detail.

1. Taking into account the fire risk calculation formula, the fire risk is an important factor that affects the final value. 
In different countries and even within a single country, there are different mathematical models for calculating the fire risk. The results of calculations also may differ greatly. Given that the final value of the individual fire risk is a linear function of the above mentioned frequency, the 'error' has a linear effect on the final result. In addition, statistical data is used to determine the fire risk using the Methodology (Order of the RF Ministry of emergency situations No. 404 dated 10 July 2009). In this case, the fire risk is the ratio of the average number of fires per year at the same type of objects to the number the objects. If the number of fires is an exact value, since statistical data are taken from the information on fires from the authorities that record fires, then it is not possible to calculate the total number of similar objects, since the corresponding accounting is not maintained. In other words, one has to use assumptions. In addition, for each fire, they record the information about the functional purpose of the fire building, its fire and technical characteristics, etc. In this case, the duration of the object's operation during the day, during the year, etc. is not taken into account. So the value of the fire risk can not be considered reliable. The selection of this value is made by the specialist who performs the calculations.

2. Calculations are based on the design and use of certain models of the occurrence and spread of fire, the spread of fire hazards, as well as evacuation. Any model, even the ideal one, does not allow describing the real picture of the processes. It means that it a priori assumes the presence of a whole set of assumptions.

3. However, the main contribution to the correct calculations is made by the level of qualification of the operators. Moreover, the level of qualification should be understood not only as the level of knowledge, but also as scrupulousness, that is, the ability to accurately follow the rules and show accuracy in performing tasks.

Calculations of the spread of fire hazards and the time of evacuation are carried out using software that allows creating graphical models of space-planning solutions of buildings. They include the geometric dimensions of rooms, doors, location of equipment and furnishings, etc. The more accurately the specialist reproduces the model, the more accurate are the results obtained. In addition, it is necessary to study the fire hazard of the object thoroughly and to select the main fire load that affects fire spread and its location.

Even more important is selecting fire scenarios. The more scenarios the specialist considers and calculates, the more correctly they estimate the risk for each of the scenarios, the more reliable are the results obtained. Since the scenarios for calculating fire hazards and evacuation time may differ (in the first case, the fire source is selected in the place where the fire can develop most intensively, and in the second, the escape routes are blocked), the final result depends on the experience of the specialist and their understanding of the fire spread patterns.

It is also a typical error to determine the time of fire hazards blockingwith the indication of a deliberately low burning area or parameters of a typical fire load with incorrect values. These parameters include: lower heat of combustion, linear velocity of flame spread, specific mass burnout rate, combustion efficiency, powerweight ratio, smoke generation ability, oxygen consumption $(\mathrm{O} 2)$, release of carbon dioxide $(\mathrm{CO} 2)$, carbon monoxide $(\mathrm{CO})$, and hydrogen chloride $(\mathrm{HCl})$. There are situations when the lack of qualified specialists results in using routes and doors that are not meant for evacuation in accordance with the requirements of normative legal acts on fire safety in construction diagram of the evacuation and subsequent computational studies that determine the evacuation time. The use of deliberately false source data (an underestimated number of people on the premises, incorrect operation time of the building, the start of evacuation when modeling without taking into account the delay in accordance with the provisions of the methods, etc.) can lead to misleading results. Thus, the quality and reliability of the fire risk calculation can be improved by taking into account the above mentioned factors. 


\section{CONCLUSIONS}

The results obtained showed that the buildings of the cluster animal industrial complex, taking into account the size of the individual fire risk, meet the fire safety requirements. After the introduction of the fire risk assessment system at the legislative level, the owners of objects have received the opportunity to optimize the cost of fire safety and the required level of human safety. At the same time, the imperfection of calculation methods and the significant influence of subjective factors on their results makes it necessary to treat fire risk calculations as a tool for assessing the level of fire safety of an object, but in no case as the final result of this assessment.

\section{REFERENCES}

Annex to the Order of the RF Ministry of emergency situations No. 382 dated 30 July 2009.

Annex to the Order of the RF Ministry of emergency situations №404 dated 10 July 2009.

Arvidsson, F. H. (2006). Analysing Fire Risk in Automated High Bay Warehouses. Applying the IEC model for risk analysis on high bay warehouse fires. Department of Fire Safety Engineering Lund University, Sweden, Report 5203, Lund, 102.

The technical regulation about requirements of fire safety. Federal Law No. 123-FZ dated 22 July 2008.

On technical regulation. Federal Law No. 184-FZ dated 27 December 2002.

The technical regulation about safety of buildings and constructionsFederal. Law No. 384-FZ dated 30 December 2009.

Gordienko, D. M., Shebeko, Yu. N., Shebeko, A. Yu., \& Kirillov, D. S. (2012). Manual for Determining the Calculated Values of Fire Risk for Production Facilities. Moscow: VNIIPO.

Ingason, H. \& Hammarstrom, R. (2010). Fire test with a front wheel loader rubber tyre. SP Report, 64. 21. SP Technical Research Institute of Sweden.

Koshmarov, Yu. A. (2000). Forecasting Fire Hazards indoors. Moscow: Academy of state fire service of the RF Ministry of emergency situations.

Maluk, C. (2017). Motivation, drivers and barriers for a knowledge-based test environment in structural fire safety engineering science, Fire Safety J., 91, 103-111. https://doi.org/10.1016/j.firesaf.2017.05.009.

Molchadsky, I. C. (2005). Fire in the Building. Moscow: VNIIPO.

NFPA 204 Standard for Smoke and Heat Venting (2012 Edition).

McGrattan, K. , McDermott, R. , Weinschenk, C. \& Forney, G. (2013). Fire Dynamics Simulator. Technical Reference Guide (6th ed.). Special Publication (NIST SP). National Institute of Standards and Technology, Gaithersburg, MD. https://doi.org/10.6028/NIST.sp.1018 (Accessed March 18, 2021).

NIST Special Publication 1019: Sixth Edition, Fire Dynamics Simulator User's Guide, National Institute of Standards and Technology, VTT Technical Research Centre of Finland, 201, 262.

About approval of the Procedure for conducting anti-corruption examination of regulatory legal acts and projects. Order of the Ministry of Emergency Situations of Russia dated 30 June 2009 No. 382 registered in the Ministry of Justice of the Russian Federation on 06 August 2009, registration No. 1448 
Order of the RF Ministry of emergency situations No. 404 dated 10 July 2009 registered in Ministry of justice of the Russian Federation on 17 August 2009, registration No. 14541.

Order of the RF Ministry of emergency situations No. 649 dated 14.12.2010.

Birgit, Ö, Daniel, B., \& Håkan, F. (2017). Fire safety engineering in timber buildings. Fire Safety J., 91, 11-20. https://doi.org/10.1016/j.firesaf.2017.05.002

Overholt, K. J., Cabrera, J., Kurzawski, A., Koopersmith, M., \& Ezekoye, O. A. (2012). Characterization of fuel properties and fire spread rates for little bluestem grass. Department of Mechanical Engineering, University of Texas, Austin, USA, 31.

Pathfinder User Manual 2017, Thunderhead Engineering, Manhattan.

ProfilArbed - Centre de Recherches, Competitive steel buildings through natural fire safety concept. Part 4, Statistics, 1999.

Puzach, S. V. (2005). Methods for Calculating Heat and Mass Transfer in an Indoor Fire and Their Application in Solving Practical Tasks of Fire and Explosion Safety. Moscow: Academy of state fire service of the RF Ministry of emergency situations.

Rahikainen, J., \& Keski-Rahkonen, O. (1998). Determination of Ignition Frequency of Fires in Different Premises in Finland, Fire EUROFIRE '98. Fire Safety by Design Engineering\& Management, Third European Symposium, Brussels, 11-13 March 1998.

Ramachandran, G., (1979). Statistical Methods in Risk Evaluation. Fire Safety Journal, 2( 80), 125-145.

Resolution of the Government of the Russian Federation dated 31 March 2009 No. 272

Robertson, A. Reducing the Risk of Fire on Your Farm, Ontario, OMAFRA, 44. Retrieved from: http://www.omafra.gov.on.ca/english/engineer/barnfire/toc.pdf

Rutstein, R. (1979). The Estimation of Fire Razard in Different Occupancies. Fire Surveyor, 8(2), 21-25.

SFPE 2002. Handbook of Fire Protection Engineering (3rd ed.). SFPE, NFPA, 2002, 1604.

SITIS 4-11: 6036-MP2 Recommendations for using the FDS software using the PyroSim 2010-2 and SmokeView software 2011. Ekaterinburg, SITIS LLC.

Standards Russian Federation (2009). Fire fighting systems.Evacuation routes and exits (SP 1.13130.2009).

Standards Russian Federation (2009). Fire fighting systems.Internal fire water main.Fire safety requirements (SP 10.13130.2009).

Standards Russian Federation (2009). Defining the categories of premises, buildings and outdoor constructions for explosion and fire risk (SP 12.13130.2009).

Standards Russian Federation (2012). SNiP 23-01-99 Building climatology (SP 131.13330.2012).

Standards Russian Federation (2012). Fire fighting systems.Ensuring fire resistance of the assets to be protected (SP 2.13130.2012).

Standards Russian Federation (2009). Fire fighting systems. Alarm system and evacuation management during fire. Fire safety requirements (SP 3.13130.2009). 
Standards Russian Federation (2013). Fire fighting systems.Limiting the spread of fire at the assets to be protected.Requirements for spatial planning and design solutions (SP 4.13130.2013).

Standards Russian Federation (2009). Fire fighting systems. Automatic fire alarm and fire extinguishing systems. Design standards and regulations (SP 5.13130.2009).

Standards Russian Federation (2012). Thermal protection of buildings.Updated version (SP 50.13330.2012).

Standards Russian Federation (2013). Heating, ventilation and air conditioning.Fire safety requirements (SP 7.13130.2013).

Standards Russian Federation (2009). Fire fighting systems.Sources of external fire fighting water supply.Fire safety requirements (SP 8.13130.2009).

Tillander, K., \& Keski-Rahkonen, O. (2003).The Ignition Frequency of Structural Fires in Finland 1996-99. D. D. Evans (Ed.), Fire Safety Science - Proceedings of the Seventh International Symposium (pp.1051-1062). Worcester, Massachusetts, USA, 16-21 June 2002, International Association for Fire Safety Science.

Tsuchiya, Y., \& Mathieu, J. F. Heat, CO and Smoke Release Rates of Plywood under a Depleted Oxygen Atmosphere: An Experimental Study Using an OSU Heat Release Rate Apparatus, Fire Safety Science. Proceeding of the Third International Symposium (pp.605-614).

Zernov, S. I. (1984). Development of Computational Methods for Predicting Fire Parameters in Buildings with Natural Ventilation (Unpublished master's thesis). Moscow.

Zozulya ,V. M., Bespaly, I. K., Loginov, F. L. Mileev, E. B. (1974). Fire Prevention in Industry and Agriculture. Moscow: Stroyizdat.

\section{SEMBLANCE OF THE AUTHORS}

Anatoly P. Savelyev: He is a Full Doctor in in Technical Sciences, Professor of Ogarev Mordovia State University, Russia.

Sergey V. Glotov: He is a Full Doctor in in Technical Sciences, Professor of Ogarev Mordovia State University, Russia.

Mikhail N. Chugunov: He is a $\mathrm{PhD}$ in Economics, Associate Professor of Ogarev Mordovia State University, Russia.

Svetlana A. Enaleeva: She is a $\mathrm{PhD}$ in Technical Sciences, Associate Professor of Ogarev Mordovia State University, Russia. 